\title{
Analysis of PT SH's Feed Additive Marketing Strategy Based on Competitive Setting Profile (CSP) and Company Alignment Profile (CAP)
}

\author{
Rahmat Sutono $^{1}$, Harianto ${ }^{2}$, Imam Teguh Saptono ${ }^{3}$ \\ 1,2,3Business School, Institut Pertanian Bogor, Jl. Raya Pajajaran, Bogor 16151
}

Corresponding Author: Rahmat Sutono

\begin{abstract}
PT SH is a company that distributes veterinary medicinal products produced by Lallemand Animal Nutrition (France) and several products from other suppliers. This product from Lallemand is included in the feed additive class which functions to increase livestock productivity with better feed conversion. Competition in product sales in this group greatly affects the sales of feed additives for PT SH. Therefore, this study uses CAP and CSP analysis to analyze the marketing of PT SH, and analyzes the competition between PT SH and other companies in the sale of feed additives. CAP analysis consists of marketing strategy, tactics and values, while CSP analysis consists of customer demand, competitive situation, and variable factors. CAP analysis gives an average score of 2.82, this mid score indicates that the strategies and tactics used as well as the marketing value of PT SH need to be improved in order to increase PT SH's feed additive sales. CSP analysis gives an average score of 3.56, this fairly large score indicates that PT SH's competition with other companies is quite strong in the sale of feed additives. This requires PT SH to maintain quality, improve marketing strategy services to increase sales of feed additives, so that PT SH is not left behind by other companies.
\end{abstract}

Keywords: CAP analysis, CSP analysis, Mix, Feed additive, Marketing.

\section{PRELIMINARY}

Every company, whether engaged in products or services, has the same goal, which is to gain profit. In the development of the business world, companies are required to display the best products and can meet the purchasing power of consumers. Therefore, the company must implement a pattern of professional management in the company's operations so that the company will be able to achieve its goals and the company will continue to run. One of the steps taken is to increase sales volume. The company must stay alive and develop, and always be able to increase its sales volume. For that the company must have a strategy, by taking advantage of existing opportunities.

Strategy for the company is one of the most important factors, because the strategy in the company can be used as a foothold and guide in achieving company goals in relation to long-term goals. Even with a strategy, it is expected that the leader or manager of a business or company can carry out their business activities well so that they can compete and maintain their business among their competitors. Supranto $\mathrm{J}$ and Limakrisna (2011) said that in this era of globalization, competition is very tough. Marketers who will sell their products in the form of goods or services in order to win the competition must be able to meet what their consumers need and want, thereby providing a better consumer value.

Burnes (2003) explains that the concept of strategy at the business entity stage is divided into 2 parts, namely survival and confrontation strategy. In the concept of survival strategy, reinforcement is needed 
that aims to maintain and strengthen a competitive position in an organization/company by focusing on core competencies (Johnson and Scholes, 1999) and cost efficiency (Cole, 1994). Currently, there are many companies that produce similar products or services, to be able to compete, a company needs to recognize the company's strengths and weaknesses, and take advantage of every opportunity that exists and avoid or minimize the company's threats and weaknesses.

PT SH is a business entity engaged in the distribution of veterinary drugs which was founded by Dr. Ross Ainsworth is a consultant for ruminants from Australia. This company has been established since 2003 which is included in Foreign Investment. The types of products sold are feed additives, products for pain relief and deworming. PT SH has a vision to become a leading veterinary drug distributor in Indonesia.

With regard to sales efforts, the marketing or marketing programs currently being carried out by PT SH are still ineffective due to limited marketing personnel and infrastructure causing the program to run slowly. Consumer needs can change due to certain circumstances that affect the sales of PT SH. Animal feed additive products are not primary needs. The primary need for animals is quality feed. Consumers have many considerations before deciding to purchase feed additive products to be added to animal feed. In addition, the intense competition between feed additive suppliers has resulted in the struggle for consumer market share.

In facing market competition, companies must be able to understand the needs and wants of the market. In addition, the company must also review the company's current position, review the marketing strategy that has been carried out, and continue to strive to develop and make new breakthroughs from the products produced.

Conditions of high competition and sales efforts that are still ineffective, require
PT SH to rearrange its sales strategy in accordance with the current conditions of the business environment, in order to develop its business. The right sales strategy will have an impact on the development of feed additive products at PT SH so that they can compete nationally and can meet the demands of consumer needs. Therefore, a research is needed to make a marketing analysis conducted by PT SH to produce sales strategy recommendations that can be applied by the company in developing PT SH's business.This study aims to: 1) Analyze the strategies, tactics and marketing values of $\mathrm{PT} \mathrm{SH}$ in accordance with the prevailing competitive conditions; and 2) Identify and analyze the condition of customers, competitors and changes in PT SH's business environment.

\section{Feed Additive and Probiotik}

Feed additive is a material that is not a food substance added in small amounts and is intended to stimulate growth and increase the population of beneficial microbes in the digestive tract of livestock. This substance functions as a substance that triggers growth and increases feed efficiency in poultry, such as antibiotics, prebiotics, probiotics, organic acids, essential oils and enzymes (Nuningtyas, 2014).

Zakaria (2010) said probiotics are products containing live and non-pathogenic microorganisms, which are given to livestock to increase growth rates, stabilize production in breeding, feed conversion efficiency, increase nutrient absorption, animal health, increase appetite to accelerate weight gain. and improve dirt quality.

\section{Marketing and Decision Making}

Marketing is a social and managerial process in which formulating alternative marketing strategies that can be determined and implemented in the face of competitive conditions and business changes (Kotler 2009). Stanton in Swastha and Sukotjo (1995), explains that marketing is the overall system of business activities aimed 
at planning products, determining prices, promoting, and distributing goods and services that can satisfy the needs of existing and potential buyers.

Schiffman and Kanuk (2010) define decision making as choosing an action from two or more alternatives. The decision takes place in a series of stages, leading to the selection of a product from a variety of options. R. Terry (2000) says that every decision-making process will make a choice based on several criteria from two or more possible choices. The basis of decision making according to George R. Terry (2000) that applies include: intuition, experience, facts, authority, and rationality.

\section{Marketing}

Marketing is a social and managerial process in which formulating alternative marketing strategies that can be determined and implemented in the face of competitive conditions and business changes (Kotler, 2009). Stanton in Swastha and Sukotjo (1995), explains that marketing is the overall system of business activities aimed at planning products, determining prices, promoting, and distributing goods and services that can satisfy the needs of existing and potential buyers. Marketing has the aim of building mutually satisfying long-term relationships with parties who have major interests, namely customers, suppliers, and distributors in order to obtain and maintain references and their long-term business continuity (Kotler, 2002).

\section{Marketing Strategy}

Marketing strategy is a plan that outlines the company's expectations of the impact of various marketing activities or programs on the demand for products or product lines in certain target markets. Marketing programs include marketing actions that can affect demand for products, including changing prices, modifying advertising campaigns, designing special promotions, determining distribution channel choices, and so on (Chandra, 2002).
A marketing strategy is a plan that a marketing manager wants to follow. This action plan is based on an analysis of the situation and the company's goals and is a means of achieving these goals. In the sense of strategy, planning is often a process that takes place continuously in a company. Therefore, the marketing strategy of each company is a comprehensive plan in which the company hopes to achieve the predetermined goals, which in turn is to realize the goals of the company concerned (Tjipytono, 2000).

\section{Analysis of Strategic Marketing Plus 2000}

Marketing strategy is a plan that outlines the company's expectations of the impact of various marketing activities or programs on the demand for products or product lines in certain target markets. Marketing programs include marketing actions that can affect demand for products, including changing prices, modifying advertising campaigns, designing special promotions, determining distribution channel choices, and so on (Chandra 2002).

A marketing strategy is usually a plan that a marketing manager wants to follow. This action plan is based on an analysis of the situation and the company's goals and is a means to achieve those goals. In terms of strategy, planning is often an ongoing process within a company. Therefore, the marketing strategy of each company is a comprehensive plan in which the company hopes to achieve the goals that have been determined, which in turn realizes the goals of the company concerned (Tjipytono 2000).

Marketing Plus 2000 was developed by Hermawan Kartajaya whose basic idea was developed from Kenichi Ohmae's concept. The Strategic Marketing Plus 2000 framework includes company (company), customer (customer), competitor (competitor), and change (change) in an integrated manner. The Strategic Marketing Plus 2000 framework is used as a basis for modifying marketing strategies and tactics, 
and increasing company value. The purpose of the Strategic Marketing Plus 2000 analysis is to know the general picture of the business environment situation that affects the company, and the internal conditions of the company.

There are three main components of Marketing Plus 2000, namely: 1) Location of the competitive setting; 2) Strategy, tactics and values. This section is on the second layer circle; 3) Implementation, namely questions concerning What, Why and How, when implementing the strategy, tactics and values.

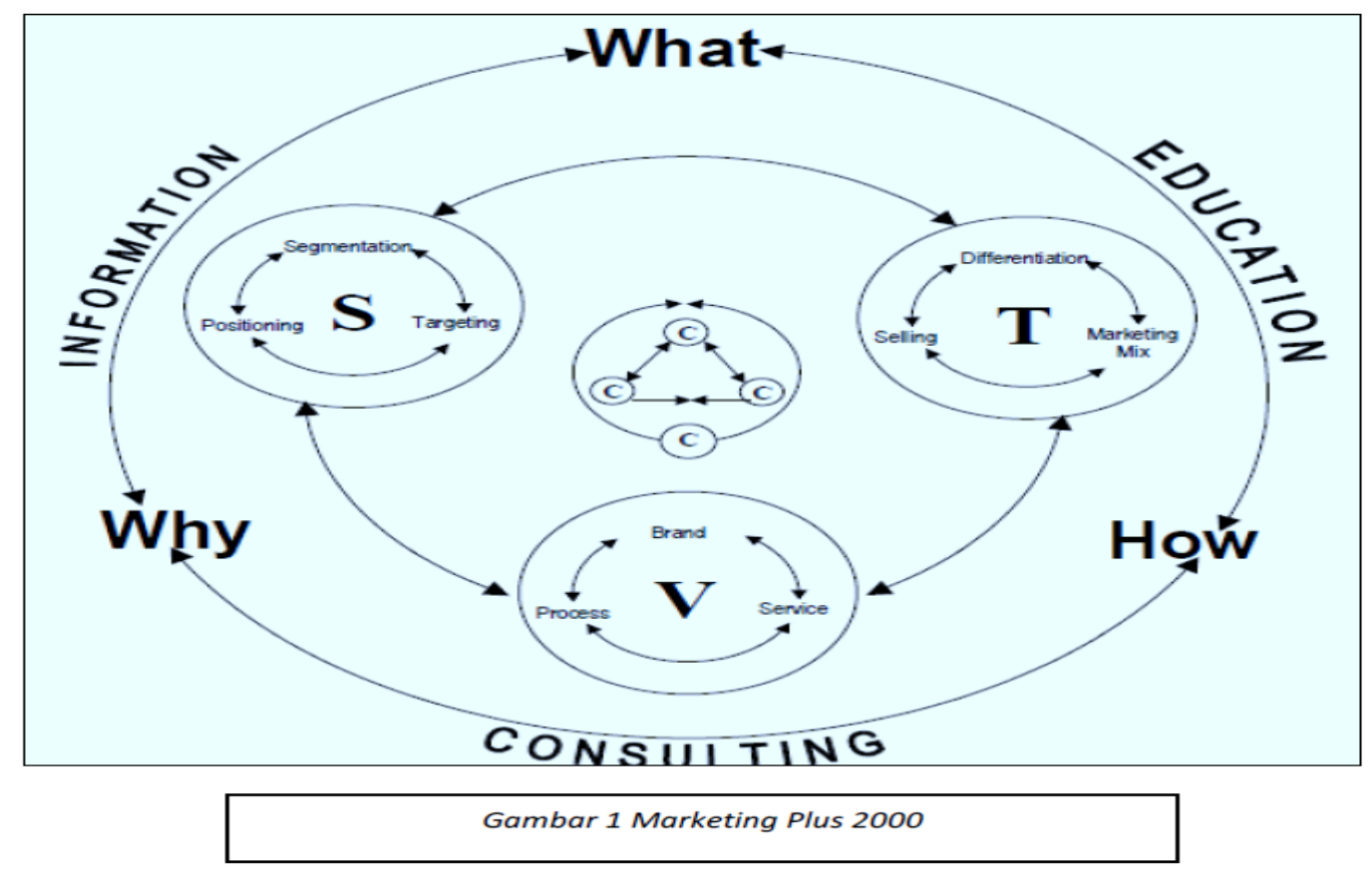

The three main components of marketing can be understood as depicted in Figure 1. In the figure there are 4 letters $\mathrm{C}$. Each letter represents Customer (C1), Company (C2), Competitor (C3), and Change (C4). These four forces affect the competitive situation. And this is what needs to be studied in understanding competition as well as formulating appropriate steps to deal with it.

\section{Company Alignment Profile dan Competitive SettingProfile}

A company can see the type of marketing orientation through the Company Alignment Index (CAI). The CAI value was obtained from the results of the CAP analysis. In Strategic Marketing Plus 2000 there are three main elements of the company, namely: strategy, values and company techniques.
A company can find out the level of competition it is facing through the Competitive Setting Index (CSI). The CSI value was obtained from the CSP analysis. In Strategic Marketing Plus 2000, the competitive situation is influenced by three components, namely: customers, competitors, and change.

\section{METHOD}

This research was conducted at PT $\mathrm{SH}$ which is located at Ruko CBD/Bidex Blok C No. 17, Jalan PahlawanSeribu BSD City, Serpong, Banten. The study was conducted from February 2020 to April 2020.

This study uses primary and secondary data. Primary data were collected through interviews, discussions, and observations by respondents. Secondary data is collected from various data releases, the Company's annual report, information 
related to the report and other supporting information.

In this study, for the company environment, 4 respondents from the management side filled out the CAP matrix, while for analyzing the industrial environment, the CSP matrix was filled with respondents from the company's external parties totaling 9 people. The method used to process and analyze the data in this research is descriptive method. This analysis aims to answer the problems that exist within the company and is carried out in the form of case studies, where data processing and analysis uses a marketing analysis concept approach (Competitive Analysis) based on the Strategic Marketing Plus 2000 framework (Kertajaya, 2005).

\section{RESULTS}

\section{Research Object Profile}

PT SH was founded by dr. Ross Ainsworth is a ruminants consultant (dairy and beef cattle). This company was purchased by Lallemand Animal Nutrition as the main supplier of PT SH. The company currently still focuses on ruminants. Most of the products sold by PT $\mathrm{SH}$ are products from Lallemand Animal Nutrition as the owner of PT SH. In addition, PT SH also sells products from other Australian companies, such as deworming medicine (Paramectin RV) from Jurox, and anti-inflammatory for cattle from Mavlab. PT SH experienced a decline from 2016 to 2018, due to an unclear business structure. The sale of these products is not through the sales team, but through agents, so that the strategy or sales targets are not clearly arranged. In addition, the company's operations have not been carried out ideally, so PT SH has problems in the product sales process. PT SH has made various efforts to overcome this. PT SH targets to develop a product selling business in poultry. PT SH also strives to cooperate with several distributors, so that PT SH's products are easier to reach customers. In addition, PT $\mathrm{SH}$ also strives to register all products, so that all products are active in sales. A very important point is to form a field sales team and maximize its operations. This is done so that the sales strategy and targets are clearly arranged, so that sales will increase. The formation of a sales team can also provide the best service for customers, such as overcoming the obstacles faced by customers in the field.

\section{Analysis of Strategic Marketing Plus 2000}

\section{Company Alignment Profile}

Company Alignment Profile (CAP) is used to determine the company's internal profile (Company / C2), including strategies, techniques, and marketing values that are currently applied. The CAP profile was taken from internal company, namely three PT SH management staff and 2 experts in the livestock industry who were deemed eligible to participate in this profile assessment. The results of the questionnaire are presented in Table 1.

R3: Executive Director of Gaspusindo

R5: Customer Service Manager PT SH

R9: Director ASOHI

R12: Director of Operations PT SH

R13: Operations Manager of PT SH

\section{Strategy}

From Table 1 it is found that the segmentation dimension produces the number 1.00. This means that in dividing its market, PT SH has not optimally divided consumers into several segments or groups based on the quality and personality of consumers in general. Targeting is determining the target market that aims to allocate company resources effectively. PT SH's targeting dimension from the strategy component obtained a score of 2.60. This has an explanation that the target market or consumer targets set by PT SH for feed additive products are people who are suitable to buy the products made (Suitable Ones), and selected people (Chosen one), only the aspect of meeting the target in several years is not achieved. This can happen because sales performance has not been able to run effectively. 
PT SH's market positioning strategy obtained an average value of 2.00. This value means that the positioning applied by PT SH for feed additive products is one statement (one statement) and one different (one different). PT SH embeds a statement in the minds of consumers that feed additives are products needed by livestock, with high quality, good service, and economical prices. Meanwhile, the products distributed by PT SH have added value that is different from the others in the form of livestock assistance and learning provided by product sales agents.

\begin{tabular}{|c|c|c|c|c|c|c|c|c|}
\hline \multirow{2}{*}{\multicolumn{2}{|c|}{ Company (C2) }} & \multirow{3}{*}{$\begin{array}{c}\text { R3 } \\
1\end{array}$} & \multirow{3}{*}{$\begin{array}{c}\mathbf{R 5} \\
1 \\
\end{array}$} & \multirow{3}{*}{$\begin{array}{c}\text { R9 } \\
1\end{array}$} & \multirow{3}{*}{$\begin{array}{c}\text { R12 } \\
1\end{array}$} & \multicolumn{3}{|c|}{ CAP } \\
\hline & & & & & & \multirow{2}{*}{$\begin{array}{c}\text { R13 } \\
1\end{array}$} & \multirow{2}{*}{$\begin{array}{c}\text { Average } \\
1,00\end{array}$} & \multirow{2}{*}{$\begin{array}{c}\text { Standard deviation } \\
0,00 \\
\end{array}$} \\
\hline Strategy & a. Segmentation & & & & & & & \\
\hline & b. Targeting & 2 & 2 & 3 & 3 & 3 & 2,60 & 0,55 \\
\hline & c. Positioning & 1 & 3 & 1 & 2 & 3 & 2,00 & 1,00 \\
\hline \multirow[t]{3}{*}{ Tactics } & a. Differentiation & 4 & 4 & 3 & 3 & 4 & 3,60 & 0,55 \\
\hline & b. Marketing Mix & 3 & 3 & 2 & 5 & 1 & 2,80 & 1,48 \\
\hline & c. Sale & 2 & 3 & 3 & 1 & 2 & 2,20 & 0,84 \\
\hline \multirow[t]{3}{*}{ Value } & a. Merk & 5 & 4 & 5 & 3 & 2 & 3,80 & 1,30 \\
\hline & b. Service & 3 & 4 & 4 & 4 & 3 & 3,60 & 0,55 \\
\hline & c. Process & 4 & 4 & 4 & 4 & 3 & 3,80 & 0,45 \\
\hline \multicolumn{4}{|c|}{ CAI Average Index } & & & & 2,82 & 0,46 \\
\hline
\end{tabular}

\section{Tactics}

The company's differentiation tactic is worth 3.60 , meaning that the company applies product differentiation that is "preferred by customer (preferred by consumers)". Feed additive products have an advantage in terms of quality, when compared to its competitors, because PT SH provides various feed additive products according to consumer needs. The marketing mix includes the 4Ps (Product, Price, Place and Promotion). Marketing mix obtained 2.80. These results indicate that PT SH's marketing mix includes the 4Ps. The average index on the sales dimension of PT $\mathrm{SH}$ gives a result of 2.20. These results indicate that PT SH's sales tactics have not been optimal with an approach to the benefits and product solutions offered.

\section{Value}

The brand dimension scored 3.80 . This means that the brand of feed additive products is quite easy for consumers to remember. The service dimension gives a score of 3.60 , this result indicates that the company does not provide satisfactory service to consumers. The process dimension gives a score of 3.80 , meaning that every part of the company has worked well together, it's just that it has not been integrated as a single company and is concerned about the company's sales.

\section{Competitive Setting Profile}

CSP analysis measures the competitive situation that occurs in the feed additive industry environment, where the company is located. The analysis discusses three aspects, namely customers (C1), competitors (C3) and changes (C4), the results of the questionnaire can be seen in Table 2. Respondents who filled out the CSP questionnaire were:

R1 : Production Manager of PT Juang Jaya Abdi Alam

R2 : Director of PT Estika Tata Tiara Tbk.

R3 : Executive Director of Gapuspindo

R4 : Sales Manager Elanco Animal Health

R5 : Customer Service Manager PT SH

R6 : Feedlot Manager Ox Dewata Makmur

R7 : Manager Neovia

R8 : Farm Manager Ultra Jaya Bandung

R9 : Director ASOHI

R10: Regulatory Manager

R11: Head Procurement of PT Austasia

R12: Director of Operations of PT Sumber Animals

R13: Operations Manager of PT Sumber Animals 
Rahmat Sutono et.al. Analysis of PT SH's feed additive marketing strategy based on competitive setting profile (CSP) and company alignment profile (CAP)

Table 2: CSP Index Value

\begin{tabular}{|c|c|c|c|c|c|c|c|c|c|c|c|c|c|c|c|c|c|}
\hline \multicolumn{3}{|c|}{ CSP } & R1 & $\mathbf{R} 2$ & R3 & R4 & R5 & R6 & R7 & R8 & R9 & R10 & R11 & R12 & R13 & Average & $\begin{array}{l}\text { Standard } \\
\text { deviation }\end{array}$ \\
\hline \multirow[t]{3}{*}{ C1 } & \multirow{3}{*}{$\begin{array}{c}\text { Customer } \\
\text { Request }\end{array}$} & Enlightened & 3,00 & 3,00 & 3,33 & 3,00 & 3,67 & 3,67 & 4,00 & 1,33 & 3,33 & 3,67 & 3,00 & 3,67 & 3,00 & 3,21 & 0,66 \\
\hline & & $\begin{array}{l}\text { Know } \\
\text { Information }\end{array}$ & 3,00 & 3,33 & 3,67 & 3,67 & 3,00 & 3,67 & 4,00 & 1,67 & 4,00 & 4,00 & 3,67 & 4,67 & 3,33 & 3,51 & 0,72 \\
\hline & & Ability & 3,50 & 3,50 & 4,00 & 3,50 & 3,50 & 4,00 & 4,00 & 1,00 & 3,00 & 4,00 & 4,50 & 4,50 & 2,50 & 3,50 & 0,94 \\
\hline & & & & & & & & & & & & & & & & 3,41 & 0,15 \\
\hline \multirow[t]{4}{*}{ C3 } & \multirow{3}{*}{$\begin{array}{c}\text { Competition } \\
\text { Situation }\end{array}$} & General & 4,25 & 3,00 & 3,50 & 3,50 & 3,25 & 3,00 & 3,25 & 4,50 & 3,00 & 4,00 & 4,75 & 3,75 & 3,75 & 3,65 & 0,58 \\
\hline & & Aggressive & 3,75 & 3,25 & 3,25 & 3,00 & 3,50 & 3,00 & 3,50 & 4,75 & 3,75 & 4,00 & 4,75 & 4,50 & 3,75 & 3,75 & 0,60 \\
\hline & & Capability & 3,75 & 3,50 & 3,50 & 3,75 & 3,25 & 3,00 & 3,50 & 4,75 & 3,00 & 3,75 & 3,75 & 4,50 & 4,00 & 3,69 & 0,51 \\
\hline & & & & & & & & & & & & & & & & 3,70 & 0,05 \\
\hline \multirow{4}{*}{$\mathrm{C} 4$} & \multirow{3}{*}{$\begin{array}{l}\text { Modifier } \\
\text { Factor }\end{array}$} & Technology & 4,25 & 3,00 & 3,50 & 3,50 & 3,25 & 3,00 & 3,25 & 4,50 & 3,00 & 4,00 & 4,75 & 3,75 & 3,75 & 3,65 & 0,58 \\
\hline & & So-Eko-Pol & 3,75 & 3,25 & 3,25 & 3,00 & 3,50 & 3,00 & 3,50 & 4,75 & 3,75 & 4,00 & 4,75 & 4,50 & 3,75 & 3,75 & 0,60 \\
\hline & & Market & 4,00 & 4,00 & 4,00 & 3,00 & 3,00 & 3,67 & 3,00 & 2,67 & 3,00 & 3,00 & 1,67 & 4,67 & 4,00 & 3,36 & 0,79 \\
\hline & & & & & & & & & & & & & & & & 3,59 & 0,11 \\
\hline \multicolumn{11}{|c|}{ CSP Average Index } & & & & & & 3,56 & 0,66 \\
\hline
\end{tabular}

\section{Customer Request}

The enlightened dimension scored 3.21. This means that customers are aware of the quality of feed additives from PT SH, and the benefits of feed additive products to their livestock, due to the increasing amount of information and the ease of obtaining information about the product. The "Know information" dimension obtained an average score of 3.51. This means that the level of customer information is quite high about product quality, price and variety of feed additive product promotions.

The third dimension measured in customer demand is "capability". The mean of these dimensions is 3.50. This means that the level of influence of product prices on the purchase of feed additives from PT SH, brand loyalty and the number of purchases in the next five years is quite high.

\section{Competitor}

The "General" dimension obtained an average score of 3.65. This illustrates that the conditions faced by competitors in the feed additive environment for livestock in the next five years are increasing, marked by the arrival of new competitors. The competitor's strategy for the next five years is likely to be high, as can be seen from the competitor's “Aggressiveness” profile index of 3.75. These results pose a serious threat to $\mathrm{PT} \mathrm{SH}$, so that $\mathrm{PT} \mathrm{SH}$ is required to maintain the quality of feed additive products and use competitive prices. The mean for the "capability" profile is 3.69. This shows that the capabilities of competitors are at a fairly high level. This is because many new companies have emerged, both as producers and distributors. In addition, manufacturing companies always carry out product development and provide the best service.

\section{Change}

For the "Technology" dimension, the average score is 3.65. This means that advances in media technology for ordering goods, the frequency of updates and media promotions are quite large in influencing changes in PT SH's sales. For the "socioeconomic-political" dimension, the respondents think that the impact on change will also be quite large in the next five years. This can be seen from the results of the average index obtained from this dimension, which is 3.75. Similar results were also obtained on the market dimension, where this dimension obtained an average score of 3.32 , so that market conditions also greatly influenced changes in PT SH's sales.

\section{Alternative Marketing Strategy for PT SH}

From the results of the CSP analysis, an index of 3.56 was obtained, using the Markplus 2000 Conceptual Framework. The index value was included in the $3 \mathrm{C}$ (Complicated) competitive conditions. The discussion on strategic recommendations for PT SH will refer to block 3C. Each competitive condition has different characteristics of customers, competitors 
and variable factors. In the case of PT SH, the characteristics of customers for the next five years are Customers. These Customers must be distinguished from Buyers and Users. Buyers just buy products without wanting to know the characteristics of the product and want something more about the product. While the user already has a higher level of desire and expectation. So, the characteristics of the customer, the company should provide better service to meet the expectations, needs and desires of customers.

In terms of competitors, PT SH faces a "strong" competitor, where the company's competitors have a fairly high aggressiveness and the environmental conditions of the feed additive industry are "continuous". The aggressiveness of competitors is seen in the variety of products offered, packaging made with attractive colors and lower prices than PT SH's feed additive products, making them more affordable. Therefore, companies should conduct periodic evaluations of marketing aspects, especially prices so that they remain in accordance with the purchasing power of farmers and the prices are competitive.

Companies with this $3 \mathrm{C}$ position do not sell to the entire market, but choose the most effective market segments to serve. For feed additive products, the most effective segment is farmers. In addition, the company does not only make products that are better than its competitors, but what is more important is the differentiation of its products from other feed additive products that are tailored to the needs of customers (breeders). Furthermore, promotions are carried out in a balanced manner, both for direct users (farmers) and those selling feed additive products, such as dealers, subdealers and kiosks.

\section{Segmentation Alternative}

The segmentation strategy applied by PT SH is currently based on a combination of psychographics and demographics. Psychographic segmentation is in accordance with the $3 \mathrm{C}$ competitive situation faced by the company today, where the company divides the market for PT SH's consumer lifestyle in appreciating the time and benefits of using feed additive products, where practical, effective and efficient become one of the factors that determine decisions in making purchase of feed additive products.

The company should conduct research in assessing the segmentation applied by the company on a regular basis, so that it remains in accordance with the competitive conditions that occur in the feed additive industry according to various changes that may occur, such as changes in technology, social conditions of farmers and changes in people's lifestyles.

\section{Targeting Alternative}

PT SH's target market for feed additive products is people who are expected to be able to buy the manufactured products (Suitable Ones), namely breeders who need feed additives to increase livestock productivity. However, in the face of competition in the next five years in accordance with 3C competition conditions, the company can change its target market from "Suitable Ones" to "Choosen one". Choosen, one means that PT SH in targeting its market for feed additive products is a group that is considered effective, namely those who need feed additives and have knowledge of feed additives that suit the needs of farmers.

\section{Positioning Alternative}

In determining the positioning strategy, the company has implemented a strategy that is in accordance with the $3 \mathrm{C}$ competitive situation, the company makes various efforts so that the products sold are in demand and attached to the minds of consumers. Positioning is basically a perception that wants to be created through all kinds of marketing communication efforts. PT SH sells feed additive products that have guaranteed quality internationally, where these products are produced by a 
large company from France (Lallemand Animal Nutrition), so that these further fosters consumer confidence, because feed additive products are considered superior to products from other companies.

\section{Managerial Implications}

Based on these results, the analysis conducted on the Company Alignment Profile shows that the strategies, tactics and values applied by the company so far are still lagging behind the real conditions faced by the company. The CAI value obtained is 2.82, this shows that the company is in the position of Selling Oriented Company towards Marketing Oriented Company. In a sales-oriented company, the company focuses on persuasive sales methods, making product improvements and conducting mass promotions. After that, to deal with the situation of a marketingoriented company, the company can focus its activities on finding new market opportunities, namely by selecting the most effective segments to serve, increasing product innovation and differentiation, as well as an effective promotion mix.

The Competitive Setting Profile shows that consumers, competitors and the changing business environment faced by the company are currently in a complicated situation, where in this condition the company is required to treat consumers as real consumers, besides that competitors are getting stronger and changes are happening continuously. in the industry it faces. In addition, it can be seen from the negative gap between the Competitive Setting Index value and the Company Alignment Index value. This gap means that $\mathrm{PT} \mathrm{SH}$ in strategy, tactics, and values that have been implemented so far has lagged compared to competitors.

The level of effectiveness of PT SH's marketing resources in dealing with competitive conditions and business changes is included in the good category, where the company's resources have been optimal in supporting its marketing performance. It's just that the sales strategy going forward is to be more effective and efficient, and every part has a role in sales (synergy).

\section{CONCLUSIONAND RECOMMENDATIONS Conclusion}

1. The analysis conducted on the Company Alignment Profile shows that the strategies, tactics and values applied by the company so far are still lagging behind the real conditions faced by the company.

2. Competitive Setting Profile shows that consumers, competitors and changes in the business environment faced by the company are currently in a complicated situation, where in this condition the company is required to treat consumers as real consumers, besides that competitors are getting stronger and changes have occurred. continuously in the industry it faces.

\section{Suggestion}

1. This research is expected to be continued by focusing on one of the product brands sold by PT SH.

2. CAP and CSP analysis can also be applied to sales of other portfolio products, such as poultry and ruminants.

3. Research using CAP and CSP analysis can be used to compare sales of imported products with local products.

\section{Acknowledgement: None}

\section{Conflict of Interest: None}

\section{Source of Funding: None}

\section{REFERENCES}

1. Burnes B. 2003. Managing change and changing managers from ABC to XYZ. The Journal of Management Development. Vol. 22 (7): 627-642.

2. Canon, JP., William DP, Jerome MC. 2008. Pemasaran Dasar-Pendekatan Manajemen Global. Jakarta (ID): SalembaEmpat.

3. ChandraG. 2002. Strategi dan Program Pemasaran, Yogyakarta: AndiOffset. 
4. Dahniar. 2017. Analisis SWOT faktor internal dan eksternal pemasaran Crude Palm Oil (CPO) pada PT. Gawi Makmur Kalimantan Banjarmasin. Prosiding Seminar Nasional AIMI.130-140.

5. David FR. 2009. Manajemen Strategis Konsep. Edisi dua belas. Jakarta (ID): PT. SalembaEmpat.

6. David ME, David RF, David FR. 2009. The Quantitative Strategic Planning Matrix (QSPM) applied to retail computer store. The Coastal Business Journal. 8(1): 42-52.

7. DIT.JEN.NAK. 1993. IndeksObatHewan Indonesia. Edisi ke 3. Jakarta (ID): Asosiasi Obat Hewan Indonesia (ASOHI).

8. Faulkner D, Bowman C. 1997.Strategi Kompetitif.Yogyakarta (ID): ANDI

9. Fathul F, Tantalo S, Liman,Purwaningsih N. 20 13. Pengetahuan Pakan Dan Formulasi Ransum. Bandar Lampung (ID): Buku Ajar Universitas Lampung.

10. Firdaus AS, Rahmawati A, Sunarsih ES. 2015. Penyusunan rencana dan strategi program studi menggunakan metode SWOT. Jurnal Pendidikan Teknik Bangunan. Vol 6. (6).

11. Gupta NKV.2013. Gadget Dependency among Medical College Students in Delhi. Indian Journal of Community Health. 25 (4).

12. Hardjosubroto, Astuti JM. 1993. BukuPintar Peternakan. Jakarta (ID): PT Gramedia Widiasarana Indonesia.

13. Hariadi, B. 2003. Manajemen Strategis. Malang (ID): Bayumedia.

14. Hermanto. 2016. Analisis SWOT obatbatukprospan pada PT. Soho Global Health. Jurnal Metris. 17 (1): 13-20.

15. Hidayati PI. 2017. Analisis strategi pengembanganagribisnispeternakanayamras di KabupatenProbolinggoJawa Timur. Jurnal OPTIMA. (1)1: 23-31.

16. Johnson G, Scholes K. 1999. Exploring Corporate Strategy 5th Edition. London (GB): Prentice Hall.

17. Kotler P. 2009. ManajemenPemasaran. Edisitigabelas Bahasa Indonesia.Jilid 1 dan 2. Jakarta (ID): Erlangga.

18. Nuningtyas YF, 2014. Pengaruh penambahan tepung bawang putih (allium sativum) sebagai aditif terhadap penampilan produksi ayam pedaging. J. Ternak Tropika. 15 (1): 21-30.

19. SchiffmanLG,KanukLL. 2010. Consumer Behaviour, ed. ke-10. NewJersey (NJ): PearsonPrentice Hall.

20. Sumarwan U, Hartoyo, Fahmi I (Editor). 2018. Metode Riset dan Bisnis Konsumen, Edisi Revisi. Bogor (ID): IPB Press.

21. Supranto, Limakrisna N. (2011). Perilaku Konsumen dan StrategiPemasaran. Jakarta (ID): Mitra Wacana Media.

22. Swastha, B. dan I. W Sukotjo. 1995. Pengantar Bisnis Modern. Penerbit Liberty,Yogyakarta.

23. Terry GR. 2000. Prinsip-Prinsip Manajemen.Bandung: PT. BumiAksara.

24. Tjiptono F. 2000. Manajemen Jasa. Yogyakarta: Penerbit Andy.

25. Zakaria, M.A.S. 2010. Pengaruh lama penyimpanan telur ayam buras terhadap fertilitas, daya tetas telur dan berat tetas. Jurnal Agrisistem 6: 97-103.

How to cite this article: Rahmat Sutono, Harianto, Imam Teguh Saptono. Analysis of PT SH's feed additive marketing strategy based on competitive setting profile (CSP) and company alignment profile (CAP). International Journal of Research and Review. 2021; 8(12): 172-181. DOI: https://doi.org/ 10.52403/ijrr.20211223 